\title{
Patchouli Oil Farming: An Alternative to Poverty Alleviation through Smallholders Business
}

\author{
Ernawati $^{1}$, Putri Bintusy Syathi ${ }^{2}$, Syaifullah Muhammad ${ }^{3}$, Indra $^{4}$, and Hesti Meilina ${ }^{5}$ \\ ${ }^{1}$ Agriculture Faculty of Syiah Kuala University \\ ${ }^{2}$ Economics and Business Faculty of Syiah Kuala University \\ ${ }^{3}$ Engineering Faculty of Syiah Kuala University \\ ${ }^{4}$ Graduate School Program of Syiah Kuala University \\ ${ }^{5}$ Atsiri Research Centre (ARC) of Syiah Kuala University \\ $\left\{{ }^{1}\right.$ putri_syathi@unysiah.ac.id $\}$
}

\begin{abstract}
Patchouli oil farming is a farming business that has been carried out for many years in Aceh Province. This business was one of the most favored businesses, but now it has become one of the less desirable farming business because the selling prices fluctuations have discouraged farmers to continue the production. Therefore, this study examines the feasibility of patchouli cultivation as a source of smallholders' income by using business feasibility indicators. These indicators include B/C Ratio, Payback Period, and Return on Investment (ROI). The data collected through surveys based on the prepared questionnaire then analyzed qualitatively and quantitatively. The calculation result is $\mathrm{B} / \mathrm{C}$ ratio of 1,9 , ROI of $50,4 \%$ and a payback period of 7,9 months. The results of the analysis obtained indicate that the business is feasible to develop as a business for smallholders because it is profitable and has a payback period of investment in just one planting period. Furthermore, the fluctuations in patchouli oil prices did not make this business unfit to develop because this study found that the business was a feasible event when the selling price of patchouli oil was at the lowest level. However, the interest of smallholders to re-develop this business still needs to be improved and the socialization to promote this farming business as a source of income for smallholders needs to be employed as one of the local government policies in poverty alleviation efforts.
\end{abstract}

Keywords: Patchouli Smallholder, Business Opportunity, Poverty

\section{Introduction}

Your Aceh is a province that is known as a rich region based on the number of natural resources available. However, Aceh is still a region in Indonesia with a high poverty rate. According to BPS (Badan Pusat Statistik), in March 2018 the percentage of the poor in the province is $15.97 \%$ while the percentage at the national level is only $9.82 \%$. Furthermore, the central government implements small business empowerment to reduce poverty level, hence, the program also implemented at the provincial and district level. Developing small business highly related to local commodities. Tambunan [1] studied on role of micro and small enterprises confirm that the enterprises significantly important for poverty alleviation in the region (province). Moreover, the study specifically mentions that the variation of the role due to crucial inputs such as raw materials, technical assistance, etc. 
Some local commodities with unique characteristics, high quality and much needed by industry at the national level as well as export commodities such as patchouli oil, have not yet received an adequate touch on the upstream-downstream chain so that they have not had a positive impact on improving the welfare of the community. In Indonesia, patchouli is the main producer of essential oils that are exported to various countries such as France, Singapore, the United States, England, Germany, India, Spain, and the Netherlands, for the cosmetics, perfume, soap, medicine and others industries. Indonesia is a supplier of $90 \%$ of the world's patchouli oil needs and $70 \%$ of them has come from Aceh.

Aceh Patchouli has the advantage of having patchouli alcohol (PA) above 30\%. Besides that Aceh's patchy and strong patchouli oil has been accepted by the international market, so even though some other provinces such as Sulawesi have the most patchouli oil production, they still need Aceh patchouli oil to be mixed before being exported. Even so, the superiority of Aceh patchouli oil has not yet seen an impact on improving the welfare of patchouli farmers in Aceh.

Currently, farmers produced their patchouli oil traditionally and they used drums as a refining boiler which led to the low productivity and quality of patchouli oil. The oil produced from this reactor is only 1-2\% of the terna (dried patchouli leaves and stems) with an average PA content of $28 \%$, high acid content, burnt smell and high impurity content [2]. This low quality causes the selling price of patchouli oil to be relatively cheap because it cannot be used directly by the industry of patchouli oil derivative products such as the perfume industry, cosmetics, aromatherapy, etc. without further processing. Fluctuations in the market price of patchouli oil at the level of farmers that tend to adversely affect the decline in Aceh patchouli production. Patchouli farmers do not produce optimally, even some of them transfer land functions to other commodities that offer higher prices. Patchouli oil exporters also shifted their demand to patchouli from Sulawesi because Aceh's patchouli oil supply was smaller than the amount of patchouli oil demanded by patchouli oil importers on the international market.

The number of patchouli farmers, land area and patchouli oil production and fluctuations in the price of Aceh patchouli oil at the farm level in recent years are shown in the following figure.

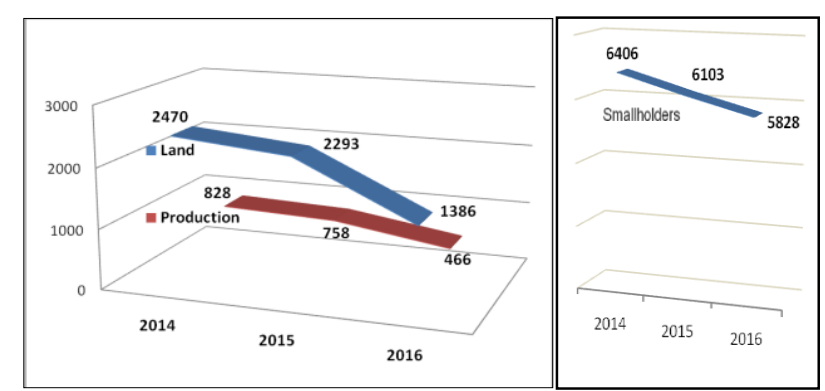

Figure 1. Patchouli Oil Production, Land Area and Number of Patchouli Farmers in Aceh Province Year 2014 - 2016 (Kg, Ha, KK)

Source: Direktorat Jenderal Perkebunan (2016)[3] 


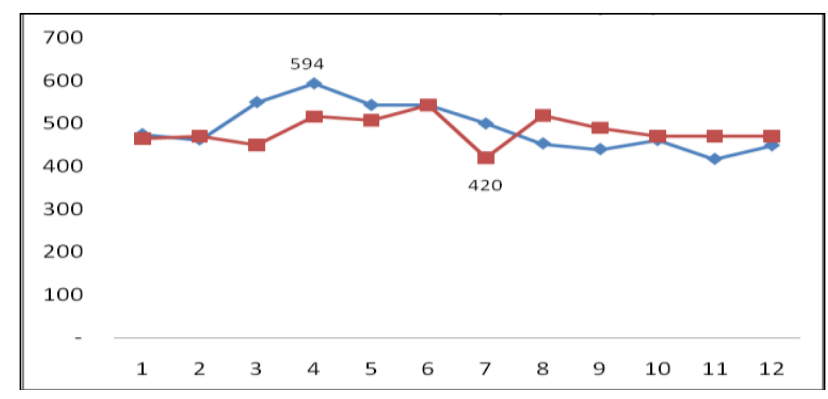

Figure 2. Patchouli Oil Prices at the Farmer Level in 2014, 2016 (January - December) Source: Direktorat Jenderal Perkebunan (2016)[3]

The decrease in patchouli area and the reduced number of farmers cultivating patchouli cultivation (as shown in Figure 1) which caused a decrease in the amount of patchouli oil production in Aceh Province, raises the question of whether fluctuations in patchouli oil market prices affect the feasibility of patchouli farming in Aceh province? For this reason, it is necessary to conduct research on investment feasibility studies on patchouli oil cultivation and refining in Aceh, considering the demand for Aceh patchouli oil, especially as an export commodity most in demand by patchouli oil importers worldwide, as recognized by PT. Haldin, one of Indonesia's essential oil exporters.

\section{Literature Review}

The increasing demand for perfume and cosmetics and fashion trends has made the export prospects of essential oils even greater, such as Patchouli Oil, Vetiver Oil, Citronella Oil, Cananga Oil, Cubeb Oil, Cajeput Oil, Lemon Grass, Cloves Oil, Sandalwood Oil, Nutmeg Oil, Pepper Oil, and Cinnamon Oil. This can be seen from the tendency of world market demand which tends to increase. Essential oils are widely developed by the United States, France, Britain, Japan, Germany, Switzerland, the Netherlands, Hong Kong, Ireland, and Canada. With the opening of the global market, more opportunities for developing essential oil markets in regional and international markets are increasingly open. This condition certainly opens up great opportunities for SMEs and companies to develop essential oil businesses in Indonesia [4]. Sari \& Hartono [5] study of the dynamics of Indonesian patchouli oil exports to the United States as the world's largest importer of patchouli oil also showed good performance from Indonesian patchouli oil exports, this was marked by positive export trends and positive Trade Specialization Index and the largest market penetration index (IPP). The results of this research also show that Indonesia's patchouli oil export competitiveness is strong.

According to Rusli [6] in general, patchouli oil agroindustry in Indonesia has not shown excellent performance, the main problem faced is the instability of production and quality. This condition is due to the fact that most of these efforts are carried out very simply in terms of the selection of planting locations, cultivation techniques, and processing the results. This also happened in Aceh. The problems faced by patchouli farmers in Aceh generally are in 4 subsystems, namely the Upstream off-farm agroindustry, Cultivation on-farm agroindustry, Downstream agroindustry and Supporting industries. The results of research conducted by Taha \& Alam [7] to find out the income and feasibility of patchouli oil industry in Lumbutarombo Village, South Banawa Subdistrict, Donggala District, shows that patchouli oil industry business is worth cultivating with an $\mathrm{R} / \mathrm{C}$ value of 1.18, with business income (net) of Rp.15,950 .375, per month. 
Furthermore, Ermiati \& Indrawanto [8], analyzing the feasibility of farming and patchouli agroindustry, showed that patchouli oil refining agroindustry of three superior varieties showed favorable and viable results. This is indicated by the positive NPV, the IRR is higher than the prevailing bank interest rate (12\% / year) and B/C Ratio> 1. Each value for the three varieties namely Lhokseumawe, Tapak Tuan and Sidikalang is NPV Rp. 28,593,027, -; Rp. 40,269,140, -; and Rp.27,607,139, -. For IRR Value: 9,46\%; $11.84 \%$ and 9.24\%, and B / C Ratio of 2.44; 3.03; and 2.39.This has an impact on patchouli oil production and Aceh patchouli farmers' income [2].

The patchouli oil distillation analysis conducted by Pujianto, Ferichani, \& Barokah [9] in Brebes District shows that at the medium business level as in CV. Nilam Kencana Jaya in Bantarkawung found the value of business profitability of $33.90 \%$, which was obtained by a business profit of Rp. 800,149,264.5, - with a total business cost of Rp. 2,359,672,735.5, Furthermore, Unteawati et al.[10] analyzed patchouli business in the highlands and lowlands, namely in the City of Agung Timur, Tanggamus District and in Tanjung Bintang, South Lampung District. The calculation results show that patchouli oil business in the highlands and low land is financially feasible, namely the NPV value of Rp. 15,594. 676, Net B/C ratio of 2.34, and IRR of $82 \%$ for lowlands. And the NPV value is Rp. 4,479,803, Net B/C 1.29, and IRR of $19 \%$ for highlands. The results of the feasibility analysis of patchouli farming and patchouli distillation small industries conducted by Hendrastuti, Eriyatno, Rusli, \& Soedarsono [11] in Kuningan District also showed feasibility for patchouli farming and distillation, which was obtained by farming profits of Rp. 14,019,145, - per year, and indicator value: NPV of Rp. $12,130,935$; B/C Ratio 1.35; PBP for 4.97 months, and IRR of $14.60 \%$. Whereas in the small patchouli distillation industry a profit of Rp.318,192,265 per year is obtained; NPV of Rp. 295,374,174; B/C Ratio 1.85; PBP for 1.62 months, and IRR of $62.73 \%$. In this study, the price agreement between the selling price of patchouli from farming and the purchase price of patchouli by the small refining industry is at the price of Rp. 967,344.

Business feasibility analysis uses investment criteria Benefit Cost Ratio, Payback Period Net Present Value, Return on investment, Internal Rate of Return, also used in various previous studies [12]-[21].

\section{Method}

This study uses primary data in the three districts of Aceh Province, namely Gayo Luwes District, South Aceh District, and Aceh Jaya District. The consideration of the location of the study was because statistically the highest production of patchouli fruit in this region. Primary data were obtained from 60 respondents in this case patchouli farmers and patchouli oil refiners through interviews using questionnaires. The determination of the research sample was done by purposive random sampling (random aim). Interviews were also carried out on a number of Acehnese patchouli oil collectors and exporters to support a qualitative analysis of the results of this research. To strengthen the data analysis, secondary data also sourced from the Aceh Plantation Agency are used both at the district level and at the provincial level.

Analysis of research data using a quantitative approach. Quantitative analysis to see the profits (profits) of Aceh patchouli farmers using a profit approach [22]. To see whether this farmer's business is feasible or not as a small business that has economic added value, business feasibility indicators are used including, Net Benefit Cost Ratio (B/C ratio); payback period (PBP), and Return on investment (ROI), Internal Rate of Return (IRR) and Net Present Value (NPV) [22]-[28]. 
Net Present Value (NPV) is the difference between the total present value of benefits and the total present value of costs, or the number of present values of additional net benefits over the life of the business [26]. The NPV value greater than 0 (NPV $\geq 0$ ) or positive value indicates an indication of business feasibility. Net Present Value (NPV). Mathematically NPV can be formulated as follows:

$$
N P V=\sum_{i=1}^{n} \overline{B_{i}}-\overline{C_{i}}=\sum_{i=1}^{n} N \overline{B_{i}}
$$

$\mathrm{NB}=$ Net Benefit (Benefit-Cost)

$\mathrm{B}=$ Annual Revenue X OCC (Opportunity Cost of Capital)

$\mathrm{C}=$ Annual Cost X OCC (Opportunity Cost of Capital)

$\mathrm{i}=$ discount factor $(14 \%)$

$\mathrm{n}=$ year (time)

Net Benefit-Cost Ratio (Net B/C ratio) is the ratio between net benefits that are positive and net benefits which are negative for assessing the level of efficiency of use of costs (Kadariah, 1988). Net B / C value is greater than one (Net B/C> 1) as an indication of business feasibility. Mathematically it can be stated as follows:

$$
N E T B / C=\frac{\sum_{t=1}^{n} \frac{B_{t}-C_{t}}{(1+i)^{t}}}{\sum_{t=1}^{n} \frac{C_{t}-B_{t}}{(1+i)^{t}}}
$$

$$
\begin{array}{ll}
B_{t} & =\text { Benefit at time } t \\
C_{t} & =\text { Cost at time } t \\
i & =\text { Discount Factor }(14 \%) \\
t & =\text { Project period }
\end{array}
$$

Return on Investment (ROI) analysis is used to determine the ability of capital invested in all assets to generate profits from an investment. Can be calculated using the following formula: ROI = (Net income /Investment $) \times 100 \%$

For investment feasibility, ROI is above $5 \%$.

Internal Rate of Return (IRR) is the percentage of interest rate that will produce a cash flow value to 0 . So IRR is the internal interest rate of the results of the investment carried out. The IRR value $\geq i$, the business can be run and if the IRR $\leq i$, it should not run. Internal Rate of Return can be calculated by the formula [26]:

$$
I R R=i_{1}+\frac{N P V_{1}}{\left(N P V_{1}-N P V_{2}\right)}\left(i_{2}-i_{1}\right)
$$

$i^{1}=$ discount rate when NPV is positive

$i^{2}=$ discount rate when NPV is negative

$N P V 1=N P V$ is positive

$N P V 2=N P V$ is negative

Payback Period (PBP) is a method to measure how quickly an investment can return [29]. $\mathrm{PBP}$ feasibility value is smaller than required (investor). If there is no provision for this, the 
smaller the PBP value, the better because the faster the time needed for investment returns. Payback Period can be calculated:

\section{$P B P=$ Total Investment $/$ Profit Per month}

\section{Result and Discussion}

The results showed that the average respondent had a patchouli planting area of 7000 M2 $(0.7 \mathrm{Ha})$. To carry out patchouli farming as well as patchouli oil refining, with this area, on average farmers need working capital of Rp. 22,550,000, - with an average income level of $47,520,000$. The average production of patchouli oil produced by farmers on an average land area of 0.7 ha is $110 \mathrm{~kg}$ of patchouli oil, with an average profit level of Rp. 24,970,000. The following table shows farm income and patchouli of respondents.

Table 1. Average Farming Revenue and Distillation of Respondents' Value

\begin{tabular}{|c|c|c|c|}
\hline $\begin{array}{c}\text { Patchouli Oil Prices } \\
\text { at the Farmer Level }\end{array}$ & $\begin{array}{c}\text { Price } \\
\text { per kg (Rp) }\end{array}$ & $\begin{array}{c}\text { Production } \\
\text { Average } \\
\text { (Kg) }\end{array}$ & Revenue (Rp) \\
\hline Highest price & 560,000 & 110 & $61,600,000$ \\
\hline Average price & 432,000 & 110 & $47,520,000$ \\
\hline Lowest Price & 380,000 & 110 & $41,800,000$ \\
\hline
\end{tabular}

Source: primary data (calculated, 2018)

Indicators of Farming and Patchouli Refinery Feasibility are shown in Table 2 below:

Table 2. Indicators of Farm Business Feasibility and Refining of Respondents' Patches

\begin{tabular}{|l|c|c|c|}
\hline \multicolumn{1}{c|}{$\begin{array}{c}\text { Indicator } \\
\text { Description }\end{array}$} & Highest price & Average price & Lowest Price \\
\hline Profit & Rp. 39.050 .000 & Rp. 24.970 .000 & Rp. 19.250 .000 \\
\hline $\begin{array}{l}\text { Net Benefit/ } \\
\text { Cost Ratio }\end{array}$ & 2,4 & 1,9 & 1,6 \\
\hline Payback Period & 5 months & 7,9 months & 10,2 months \\
\hline Return on Invesmen (ROI) & $159,1 \%$ & $101,7 \%$ & $74,4 \%$ \\
\hline Internal Rate of Return (IRR) & $150,9 \%$ & $93,6 \%$ & $70,3 \%$ \\
\hline Net Present Value (NPV) & Rp. $29,490,000$ & Rp. $17,130,000$ & Rp. $12,120,000$ \\
\hline
\end{tabular}

Source: Primary data (calculated, 2018)

Test results on investment feasibility show that patchouli farming and refining in Aceh Province, it meets the indicators of business feasibility. Nonetheless, what is interesting is the fact that farmers recognize the conversion of land from patchouli to other plantation commodities such as oil palm, as well as other volatile plants such as fragrant lemongrass, which are perceived to offer higher prices. Farmers' recognition of this is due to the very high changes in the market price of patchouli oil offered, sometimes very high, which encourages farmers to 
produce, but at certain times, with various reasons from buyers (traders/collectors), farmers get offers a very low price. This is very disappointing, making farmers lazy to continue farming and refining patchouli. For information, patchouli oil products are not normal categories of goods which, if available in small amounts, cause prices to become expensive, otherwise, if there are large amounts of prices, they become cheap. According to one of the patchouli oil exporters interviewed, explained that if the amount of patchouli oil is available at the community level more, then the price offer from the buyers (exporters) is actually higher than if the patchouli oil stock is in small quantities. Thus, when farmers get a sharp price drop due to over-stock reasons, there are indications of a market price game at the farmer level, which may be done by collectors (small or large), or even by exporters indirectly.

The results of this study show that the conversion of land from patchouli farming to other commodities is not expected to be due to investment in patchouli oil farming that is not economically feasible. The calculation results show that even at the lowest level of patchouli oil selling price, patchouli oil farming still meets the value of the investment feasibility indicator, with an average value of farm income of $41,800,000$, - and the profit obtained by farming is Rp. 19,250,000, - per production cycle.

Although the analysis of patchouli oil farming shows economic feasibility, the decline in prices can affect the motivation of farmers to cultivate patchouli. Patchouli cultivation takes 8 months to harvest, and a grace period of 3-4 months for land can be replanted so that at the lowest price level, farmers only get an average net income of Rp. 1.6 million per month, while UMP-Aceh (2017) is Rp. 2.5 million. Of course, this condition can affect the behavior of farmers in planting patchouli. Farmers will be easy to replace the types of plants that are cultivated if the market offers a more profitable price. For this reason, it is necessary to determine the optimization of the sale price agreed at the farmer level. By using the data obtained in this study, the selling price of patchouli oil at the farmer level will be optimal at the price of Rp. 480,000 per $\mathrm{kg}$. At this price level, with an average production of $110 \mathrm{~kg}$ and an average land area of 0.7 Ha, farmers will get a net income of Rp. 30,250,000 per production cycle or an average of 2.52 million per month. This is expected to encourage farmers to remain consistent to do patchouli cultivation

\section{Conclusion}

The Patchouli smallholding is a good alternative for poverty alleviation because the business feasibility study shows a very good result. The calculation verified that even at the lowest selling price, farmers able to gain profit from the business.

Policy Implication

- Creating a unique program on Patchouli smallholders development which enlightens the farmers on the business opportunity of the patchouli farming hence encourage the farmers to develop the business side of the agricultural product.

- The government can use patchouli farming as the alternative program to reduce poverty while at the same time creating and developing a featured product for the leading sector of the Kabupaten's economic development.

- The government needs to apply regulation for a minimum price of patchouli to maintain sustainability of the society. 


\section{Acknowledgment}

We are very grateful to Project Penelitian Unggulan Universitas Syiah Kuala, 2018 that support this research financially.

\section{REFERENCES}

[1] T. T. H. Tambunan, "Peran usaha mikro kecil dalam pengentasan kemiskinan di daerah," Bina Praja J., pp. 73-92, 2012.

[2] Syaifullah, Action plan Sistem inovasi industri nilam Aceh. Aceh: Badan Perencanaan dan Pembangunan Daerah (Bappeda), 2015.

[3] Direktorat Jenderal Perkebunan, "Statistik perkebunan Indonesia Komoditas Nilam 2015-2017," Jakarta, 2016.

[4] I. K. Wardani, "Rancang bangun sistem penunjang keputusan strategi pemasaran minyak atsiri di pasar ekspor," Institut Pertanian Bogor, 2008.

[5] P. N. Sari and S. Hartono, "Analisis dinamika ekspor minyak nilai Indonesia ke Amerika Serikat,” Agro Ekon., vol. 17, no. 1, pp. 19-28, 2010.

[6] M. Rusli, "Pengembangan minyak atsiri Indonesia," in Forum IKM Minyak Atsiri, 2006.

[7] A. . Taha and M. N. Alam, "Analisis pendapatan dan kelayakan usaha industri minyak nilam di desa Lumbutarombo kecamatan Banawa Selatan kabupaten Donggala," $e-J$. Agrotekbis, vol. 4, no. 1, pp. 91-96, 2016.

[8] Ermiati and C. Indrawanto, "Kelayakan usahatani dan agroindustri nilam," in Monograp Nilam, Bogor: Badan Penelitian dan Pengembangan Pertanian Puslitbang Perkebunan Balai Penelitian Tanaman Obat dan Aromatik, 2013, p. 135.

[9] H. Pujianto, M. Ferichani, and U. Barokah, "Analisis usaha penyulingan minyak nilam (Patchouli Oil) CV. Nilam Kencana Jaya di kecamatan Bantarkawung kabupaten Brebes," e-Jurnal Agrista, 2012.

[10] B. Unteawati, I. Noer, and M. Rofiq, “Analisis finansial usaha minyak nilam,” J. Ilm. ESAI, vol. 6, no. 3, pp. 46-54, 2012.

[11] Hendrastuti, Eriyatno, M. S. Rusli, and J. W. Soedarsono, "Optimasi penentuan kesepakatan harga nilam pada rantai pasok minyak atsiri di kabupaten Kuningan," AGROINTEK, vol. 6, no. 1, pp. 16-21, 2012.

[12] M. Florio, V. Morretta, and W. Willak, "Cost-benefit analysis and European Union cohesion policy: Economic versus financial returns in investment project appraisal," $J$. Benefit-Cost Anal., vol. 9, no. 1, pp. 147-180, 2018.

[13] S. Walyoto and J. Peranginangin, "Economic analysis of environmental and cultural impacts of the development of palm oil plantation," vol. 8, no. 5, pp. 212-222, 2018.

[14] A. Daujanov, R. Groeneveld, A. Pulatov, and W. J. M. Heijman, "Cost-benefit analysis of conservation agriculture implementation in Syrdrya province of Uzbekistan," Visegr. J., vol. 5, no. 2, pp. 48-52, 2016.

[15] Y. Wahyudin and D. Lesmana, "Analisis kelayakan ekonomi pengembangan bisnis pemanfaatan kima secara berkelanjutan," J. Mina Sains, vol. 2, no. 2, pp. 53-62, Oct. 2016.

[16] F. R. Amalia, A. Daryanto, and H. Rujito, "Comparative feasibility analysis of modern and traditional system of broiler chicken farm business,” Indones. J. Bus. Entrep., vol. 1, no. 2, pp. 90-95, 2015.

[17] C. M. Smith, K. C. Dhuyvetter, T. L. Kastens, D. L. Kastens, and L. M. Smith, "Economics of precision agricultural technologies across the great plains," J. ASFMRA, pp. 185-206, 2013. 
[18] S. Nurjanah, "Studi kelayakan pengembangan bisnis pada PT Dagang Jaya Jakarta," J. WINNERS, vol. 14, no. 10, pp. 20-28, 2013.

[19] G. Shively, An overview of benefit-cost analysis. 2012.

[20] L. F. Siregar, "Analisis kelayakan usaha penyulingan minyak nilam (Patchouli Oil) PT Perkasa Primatama Mandiri kabupaten Mandailing Natal Sumatera Utara,” Institut Pertanian Bogor, 2009.

[21] K. Selvavinayagam, Financial analysis in agricultural project preparation. Rome: Food and Agriculture Organization of the United Nations, 1991.

[22] Soekartawi, Analisis usahatani. UI Press: Jakarta, 2010.

[23] J. Shockley, "Precision agriculture cconomics and decision making - Beyond profitability," in The InfoAg Conference, 2016.

[24] A. Halim, Analisis kelayakan investasi bisnis. Yogyakarta: Graha Ilmu, 2009.

[25] S. Basalamah, M. Haming, and S. Syam, Penilaian kelayakan rencana penanaman modal. Yogyakarta: Gadjah Mada University Press, 1991.

[26] Kadariah, Evaluasi proyek analisa ekonomis. Jakarta: Lembaga Penerbit Fakultas Ekonomi Universitas Indonesia, 1988.

[27] P. Abelson, Cost benefit analysis and environmental problems. Southampton, England: Itchen Printers Limited., 1979.

[28] J. P. Gittinger, Economic analysis of agricultural projects. Baltimore and London: The John Hopkins University Press, 1977.

[29] R. Nurmalina, T. Sarianti, and A. Karyadi, Studi kelayakan bisnis. Bogor: Departemen Agribisnis FEM IPB, 2010. 